\title{
PROBLEM PENDIDIKAN ANAK TENAGA KERJA WANITA INDONESIA (TKWI) DI DESA KERUAK KECAMATAN KERUAK KABUPATEN LOMBOK TIMUR
}

\author{
JAMILUDDIN \\ Jamilbae1@gmail.com ${ }^{1}$
}

\begin{abstract}
ABSTRAK : This study aims to determine the child's education problems Indonesia Labor Women (TKWI). The type used in this research is qualitative descriptive exploratory approach. In the process of data collection researchers using participant observation, interview methods (interviews), and methods of documentation. Nurturing and raising children is a responsibility that must be carried naturally by the parents, because the child needs food, drinks, and respite care so that he can live in a sustainable manner and also be able to enjoy a decent school with. Making the role of the mother by the father, brother or grandmother has not been able to make the development of children walking normally like other children who grew up with the supervision, guidance and get a touch of affection directly a mother, which eventually resulted in not a few of the children who left the mother becomes TKW their performance declines, one of the association, even dropouts.

Key word: Children Education, Labor Women (TKW)
\end{abstract}

\section{PENDAHULUAN}

Menikah dan memperoleh anak-anak yang berperestasi, taat, berkeperibadian baik adalah impian setiap pasangan suami istri. Namun kenyataannya, dalam hidup berkeluarga tidak hanya anak yang menjadi fokus utama. Selain mendidik dan membesarkan anak, orang tua juga harus berusaha untuk memenuhi kebutuhan keluarga. Oleh karena itu, banyak dari para ibu akhirnya turut berpartisipasi dalam membantu dalam memenuhi kebutuhan keluarga. Di sinilah benturan tugas terjadi. Orang tua khususnya ibu akhirnya memainkan peran ganda.

Beberapa tahun belakangan ini banyak sekali kita lihat para warga masyarakat terutama para perempuan lebih memilih bekerja ke luar Negeri dari pada harus bekerja di desanya sendiri, dengan asumsi bahwa bekerja di luar negeri akan lebih besar penghasilan yang diperoleh daripada harus bekerja di daerah sendiri.

Keluarga adalah tempat pendidikan pertama dan utama bagi putra putri mereka. Jika mereka mendidik dengan baik maka akan lahirlah seorang generasi yang baik, begitu juga sebaliknya. Peran keluarga dalam hubungannya dengan putra serta putri mereka, tidak sebatas hanya mengasihi, melindungi, dan membesarkannya secara fisik dan ekonomis,

${ }^{1}$ Jamiluddin 
melainkan bersama-sama juga sebagai pendidik yang membimbing dan mengarahkannya kejalan kehidupan yang benar. Ibu bersama bapak berperan sebagai jembatan yang menghubungkan dunia anak dengan dunia dewasanya, menghubungkan anak dengan dunia sosialnya.

Saat ini, kita dihadapkan pada suatu kenyataan masyarakat bahwa banyak sekali anak yang kurang mendapat perhatian serta dukungan terkait masalah pendidikan mereka. Anak-anak dalam lingkungan keluarga yang seharusnya meperoleh rasa aman dan terlindungi, justru terlihat seperti anak yang tidak mempunyai pijakan nilai-nilai moral yang kokoh. Peranan orang tua atau keluarga yang memberikan rasa hangat, damai dan aman di bawah asuhanya dan sekaligus sosialisasi nilai-nilai kehidupan baik nilai-nilai sosial dan agama, sepertinya sudah mulai tidak mendapatkan perhatian.

Banyak orang tua mengeluh tidak dapat menyeimbangkan peran antara bekerja di luar dengan mengurus anak. Aktivitas pekerjaan menuntut para orang tua menghabiskan hampir sebagian waktu kesehariannya ditempat kerja. Akibatnya, pengawasan dan perhatian pada anak menjadi berkurang.

Masuknya era melinium yang diistilahkan kerja serba mesin (misalnya penggunaan pestisida dan mesin traktor) mendesak posisi wanita ke pinggiran dalam memperebutkan kesempatan ekonomi. Masuknya sistem tebasan dan huller (traktor) dalam sistem pertanian telah mempersempit kesempatan kerja bagi wanita pedesaan.

Akhirnya ada dua bentuk respon yang dilakukan wanita desa untuk menghadapi struktural akibat masuknya era melinium tersebut. Pertama, wanita kembali memasuki wilayah domestik karena kesempatan kerja di sektor publik makin sulit diraih. Kedua, mereka berusaha memperoleh kesempatan kerja di luar desanya (di kota) dengan melakukan migrasi. Ada yang bermigrasi secara ulang antara desa-kota, ada juga yang bermigrsi dalam jangka panjang, dan tidak sedikit pula yang bekerja jauh di luar negeri.

Keluarga mempunyai fungsi yang tidak hanya sebatas pemenuhan kebutuhan seharihari, akan tetapi keluarga merupakan sumber pendidikan yang utama karena segala pengetahuan dan kecerdasan intelektual anak diperoleh dari orang tua dan anggota keluarga yang lain. Namun kebanyakan keluarga pada masa kini telah menyerahkan sepenuhnya fungsi pendidikan anak pada lembaga-lembaga pendidikan formal maupun non formal, sementara mereka disibukkan mencari materi dan akhirnya keluarga tidak lagi menjadi tempat yang utama bagi anak-anaknya.

Apalagi dimasa sekarang ini, kesempatan untuk menambah pendapatan keluarga juga banyak dimiliki oleh wanita terutama sebagai ibu rumah tangga sekarang terbuka 
lebar kesempatan untuk bekerja keluar negeri sebagai (TKW) yakni sebagai pembantu ibu rumah tanga, mereka rela menjadi pembantu rumah tangga di negeri orang seperti Arab Saudi, Brunai ataupun malaysia dengan harapan meperoleh gaji jutaan rupiah. Sehingga dengan kondisi inilah penulis merasa tertarik untuk mengetahui seperti apa problem atau masalah Pendidikan Anak Tenaga Kerja Wanita Indonesia (TKWI) Di Desa Keruak Kecamatan Keruak.

\section{Tenaga Kerja Wanita (TKW)}

Tenaga kerja merupakan faktor produksi yang memiliki peranan penting dalam proses produksi. Tenaga kerja adalah kemampuan manusia untuk mengeluarkan usahausaha tiap satuan waktu guna menghasilkan barang atau jasa baik itu dirinya sendiri atau untuk orang lain.

Ketenaga kerjaan berasal dari kata dasar tenaga kerja yang artinya segala hal yang berhubungan dengan tenaga kerja pada waktu sebelum dan sesudah masa kerja. Tenaga kerja menurut pasal 1 undang-undang No. 14 Tahun 1969 tentang ketentuan pokok Mengenai Tenaga kerja adalah tiap orang yang mampu melakukan pekerjaan baik di dalam maupun di luar hubungan kerja guna menghasilkan jasa atau barang untuk memenuhi kebutuhan masyarakat (Buruh dan PNS, Militer, Angkatan kerja dan sebagainya). ${ }^{2}$

Berdasarkan pengertian di atas dapat disimpulkan bahwa tenaga kerja merupakan suatu bentuk kegiatan supaya pindah ke negara lain untuk dapat memperoleh barang dan jasa supaya dapat memenuhi kebutuhannya kegiatan yang dilakukan oleh orang tersebut khususnya disebut dengan istilah "merantau" untuk lebih jelasnya berarti migrasi tetapi merantau adalah tipe khusus dari migrasi dengan konotasi budaya tersendiri yang tidak mudah untuk diterjemahkan oleh bahasa inggris atau bahasa manapun.

Inti dari pada tenaga kerja ini adalah kesadaran manusia karena tenaga yang di lakukan manusia sesuai otot-otot juga sangat berperan sehingga tenaga kerja merupakan kemampuan manusia untuk melakukan suatu pekerjaan baik secara pisik ataupun pisikis guna menghasilkan suatu barang atau jasa untuk memenuhi.

Namun dalam pengertian ini yang penulis maksud adalah warga Negara Indonesia yang melakukan pekerjaan keluar negeri untuk meningkatkan taraf hidup serta memperbaiki keadaan ekonomi keluarga baik dalam faktor pertanian industri, ataupun

${ }^{2}$ Djumialdji, F.X, Perjanjian Perburuhan dan Hubungan Perburuhan Pancasila, (Jakarta: Sinar Grafika, 1982), 23. 
sebagai pembantu rumah tangga dengan mengadakan perjanjian kerja terlebih dahulu dengan pihak yang bersangkutan dalam jangka waktu yang disepakati.

\section{Problem-Problem Pendidikan Anak (TKW)}

Menurut Martin S. Weinberg (dalam Kamanto), masalah sosial adalah situasi yang dinyatakan sebagai sesuatu yang bertentangan dengan nilai-nilai oleh warga masyarakat yang cukup signifikan, dimana mereka sepakat dibutuhkannya suatu tindakan untuk mengubah situasi tersebut.

Banyak orang tua yang bingung menghadapi perubahan sikap anaknya yang tiba-tiba tidak mau sekolah dengan berbagai alasan, mulai dari sakit perut, sakit kepala, sakit kaki dan seribu alasan lainnya. Bagi orang tua yang anaknya masih kecil, pemogokkan ini tentu bikin pusing karena menimbulkan kebingungan apakah alasan tersebut benar atau hanya dibuat-buat.

Orang tua menjadi bingung: memaksa anak untuk tetap berangkat sekolah takut nanti anaknya menjadi stres, atau kalau ternyata benar apa yang dikemukakan anak, lantas bagaimana harus bersikap? Sementara itu problem yang hampir sama dialami orang tua yang bingung menghadapi penolakan anaknya yang sudah waktunya bersekolah tapi masih saja belum mau masuk sekolah.

Termasuk faktor terbesar yang menyebabkan terjadinya dekadensi moral pada anakanak dan terbentuknya kepribadian yang buruk pada diri mereka adalah kurangnya perhatian kedua orang tua untuk mengajarkan akhlak yang mulia kepada si anak dan dikarenakan kesibukan mereka hingga tidak ada kesempatan untuk mengarahkan dan mendidik anak-anaknya.

Apabila seorang ayah tidak lagi peduli terhadap tanggung jawabnya untuk mengarahkan dan mendidik serta mengawasi anak-anaknya, dan dikarenakan faktor tertentu, si ibu kurang menunaikan kewajibannya dalam mendidik si anak maka tidak diragukan lagi si anak akan tumbuh seperti anak yatim yang tidak memiliki orang tua, ia hidup bagai sampah masyarakat, bahkan suatu saat akan menjadi penyebab terjadinya kerusakan dan kejahatan di tengah-tengah masyarakat.

"Anak yatim bukanlah anak yang ditinggal mati oleh kedua orang tua hingga ia menjadi miskin. Akan tetapi, anak yatim yang sebenarnya ialah seorang anak yang menemukan ibunya yang kurang mendidiknya dan menemukan ayah yang sibuk dengan pekerjaannya.",

\footnotetext{
${ }^{3}$ Abdullah Nasihin Ulwan, Tarbiyatu al-Aulaad Fii al-Islaam, (Jakarta: Pustaka Amani, 2012), 103.
} 
Ibnu Qayyim Rahimahullah berkata, "Barangsiapa yang tidak mengajarkan hal-hal yang bermanfaat kepada anaknya dan membiarkan begitu saja, berarti dia telah mendurhakai anaknya. Betapa banyak anak-anak yang rusak dikarenakan ulah ayah-ayah mereka sendiri yang membiarkan mereka begitu saja, tidak mengajarkan kepada mereka kewajiban-kewajiban dan sunnah-sunnah dalam agama Islam yang harus ia kerjakan. Mereka telah menyia-nyiakan anak mereka sewaktu kecil, sehingga mereka tidak bermanfaat untuk diri mereka sendiri dan mereka pun tidak bisa memberikan manfaat sedikit pun disaat orang tuanya sudah lanjut usia.

Sebagaimana celaan sebagian orang tua yang dilontarkan kepada anaknya dan si anak menjawab, "Wahai ayahku, sesungguhnya engkau telah mendurhakaiku di saat aku masih kecil, maka setelah besar aku pun mendurhakaimu. Engkau telah menyianyiakanku sewaktu aku masih kecil maka aku pun menyia-nyiakan engkau ketika engkau sudah lanjut usia."

Sesungguhnya kepedulian kedua orang tua tidak hanya terbatas memberikan pengajaran kepada mereka. Akan tetapi, mereka harus dibimbing dan dibantu dalam mempraktekkan bagaimana cara berbakti kepada kedua orang tuanya, tentu dengan cara dan perlakuan terbaik. Akan tetapi, jika orang tua tidak peduli akan pendidikan akhlak mereka maka si anak akan menjadi duri bagi kedua orang tuanya, karena berbakti kepada kedua orang tua merupakan sifat yang tidak akan muncul begitu saja tanpa melalui pengajaran.

\section{Peranan Orang Tua dalam Mendidik Anak}

Peranan adalah tindakan yang dilakukan seseorang dalam suatu peristiwa, peranan dapat membimbing seseorang dalam berprilaku, karena fungsi peranan sendiri adalah: Memberi arah pada proses sosialisasi, Pewaris tradisi, kepercayaan, nilai, norma, dan pengetahuan, Dapat mempersatukan kelompok atau masyarakat dan Menghidupkan sistem pengendali dan kontrol sosial sehingga dapat melestarikan kehidupan masyarakat. ${ }^{4}$

Peranan dikatakan sebagai perangkat harapan-harapan yang dikenakan pada individu yang menempati sosial tertentu, harapan tersebut sehubungan dengan norma sosial dan oleh sebab itu dapat dikatakan peranan itu di tentukan oleh norma di dalam masyarakat dan setiap individu akan melaksanakanperanannya sesuai status sosial masing-masing dalam masyarakat.

${ }^{4}$ J. Dwi Narwoko dkk. Sosiologi Teks Pengantar dan Terapan. (Jakarta: Kencana Media Group 2004) , 159. 
Keluarga sebagai pusat pendidikan yang pertama dan utama. Kalau dipikir secara mendalam siapa yang sebenarnya harus bertanggung jawab terhadap pendidikan anak maka tidak ada jawaban orang lain kecuali orang tua. Orang tua merupakan pendidikan yang utama dan pertama bagi anak-anak mereka, karena dari merekalah anak mulai menerima pendidikan. Dengan demikian bentuk pendidikan yang pertama diterima oleh anak adalah pendidikan dalam keluarga.

Konsep pendidikan Ki Hajar Dewantara "pendidikan yaitu tuntutan didalam hidup tumbuhnya anak-anak". Adapun maksudnya pendidikan itu menuntun segala kekuatan kodrat yang ada pada anak-anak itu, agar mereka sebagai manusia dan sebagai anggota masyarakat dapatlah mencapai keselamatan dan kebahagiaan yang setinggi-tinginya. ${ }^{5}$

Pendidikan dalam keluarga pada umumnya bukan berangkat dari kesadaran dan pengertian yang lain dari pengetahuan mendidik, melainkan secara kodrati suasana dan strukturnya memberikan kemungkinan untuk membangun situasi pendidikan. Situasi pendidikan itu terujut berkat adanya pergaulan dan hubungan yang berpengaruh secara timbal balik antara orang tua dan anak. Oleh karena itu orang tua memegang peranan dan pengaruh yang sangat penting atas kondisi anak-anaknya.

Adanya kesadaran mendidik dan membina anak secara kontinu perlu dikembangkan kepada setiap orang tua sehingga pendidikan yang dilakukan tidak lagi berdasarkan kebiasaan yang dilihat dari orang tua, tetapi telah disadari oleh teori-teori pendidikan modern. Sesuai dengan perkembangan Zaman yang cenderung selalu berubah. ${ }^{6}$

Kedudukan suami istri dan orang tua ditentukan oleh kewajiban-kewajiban di dalam keluarga maupun masyarakat luas. Dengan menentukan pekerjaan-pekerjaan tertentu para lelaki di luar rumah tangga, masyarakat juga ikut menentukan pembagian kerja di dalam keluarga, sama halnya dengan apa yang dikerjakan anak-anak dan orang tua di dalam keluarga membentuk tugas-tugas apa yang akan diberikan kepada mereka di luar keluarga. Orang tua berkewajiban untuk pertama kali mensosialisir anak-anak mereka, tetapi dengan demikian pula mampertahankan kontrol sosial atas mereka jika mereka meninggalkan rumah. ${ }^{7}$

Adapun peranan-peranan orang tua terhadap pendidikan anak yang akan dibahas disini diantaranya sebagai berikut:

\footnotetext{
${ }^{5}$ Hasbullah. Dasar-dasar Ilmu Pendidikan. (Jakarta: PT, Raja Grafindo Persada 2005) ,4.

${ }^{6} \mathrm{Ibid}, \mathrm{hlm} 88$

${ }^{7}$ William J. Goode, Sosiologi Keluarga. (Jakarta: PT. Bumi Aksara 2004), 136.
} 


\section{Peranan Ibu dalam mendidik anak}

Ditinjau dari kehidupan keluarga secara keseluruhan, ibu berperan sebagai "ratu rumah tangga" yang mengemudikan bahtera rumah tangga. Oleh karena itu ia memegang peranan yang sangat vital bagi terciptanya suatu iklim yang baik, yang selanjutnya dapat memberikan kondisi kepada teciptanya suatu situasi pendidikan dalam keluarga.

Peranannya sebagai ratu rumah tangga itu, pertama-tama ialah berkaitan dengan tatalaksana ke rumah tanggaan, tata laksana makanan dan tata laksana busana atau pakaian. Peranannya ini, kadang dianggap kurang berarti, sebenarnya tidak sederhana dugaan orang.

Istri Dalam masyarakat modern, dituntut pula untuk menunaikan tugasnya diluar keluarga, realisasi peranan ratu rumah tangga itu mengalami perubahan yang cukup mendalam. Sebab betapapun seorang istri itu sudah bekerja di luar rumah, namun "kehadirannya" di dalam keluarga tetap diperlukan. Mungkin kehadirannya dalam keluarga itu tidak harus secara fisik, namun setidak-tidaknya dapat dirasakan oleh seluruh anggota keluarga. Ketentraman dan keasrian rumah tidak semata-mata di tentukan kehadirannya secara fisik, melainkan mengandung pula segi-segi psikologisnya, sehingga rumah tersebut terasa "keterhuniannya" oleh sang ratu rumah tangga. ${ }^{8}$

Demikianlah dimasa sekarang ini, dimana seorang istri tidak jarang mempunyai pekerjaan yang barang kali sama beratnya dengan sang suami, dalam keluarga ini tetap tidak kehilangan perannya sebagai ratu rumah tangga. Itulah sebabnya maka sering dikatakan bahwa seorang istri sekarang memiliki peran ganda atau barang kali multiperanan. Kewanitaan yaitu memberikan sesuatu "cap" atau pola khusus terhadap segala kebijakan dan tindakannya baik dalam kehidupan keluarga maupun diluar kehidupan keluarga.

Masyarakat mempunyai suatu gambaran dan harapan tertentu tentang penampilan wanita. Misalnya ada gambaran bahwa wanita itu halus dan lembut perasaannya luwes dan indah penampilannya, sikapnya yang penyabar namun tabah dalam menghadapi kekurangan dan kesulitan dalam kehidupan keluarga dan sebagainya. Gambaran ini memang berbeda dari daerah yang satu ke daerah yang lain, dan waktu dulu dan masa sekarang. Gambaran wanita dewasa ini diantaranya berkat apa yang disebut "emansipasi wanita" telah jauh berubah dibanding dari gambaran wanita zaman dahulu. Wanita tidak

\footnotetext{
${ }^{8}$ Suherman. Psikologi Keluarga. (Jakarta: PT. Rineka Cipta, 2003), 127.
} 
lagi dipandang sebagai mahluk lemah, pasrah dan hanya pantas untuk hiasan rumah, akan tetapi telah tampil sebagai wanita yang seimbang dengan pria yang berperan dalam kehidupan keluarga.

Berkaitan pula dengan peranannya sebagai wanita, maka dalam kehidupan keluarga ia memegang perannya sebagai yang mengandung dan melahirkan anak. Peranan ini khusus untuk wanita, yang memang telah diciptakan dan disiapkan untuk peranannya ini. Dalam hubungannya dengan seorang suami, ibu berperan sebagai seorang istri, sebagai rekan suami dalam mengemudikan kehidupan keluarga, kerukunan, keharmonisan, dan kesearahan antara mereka berdua mewarnai pula iklim tersebut.

Dalam hubungannya dengan anak, ibu berperan sebagai seorang ibu, sebagai ibunya, yang merupakan kaitan yang pertama dan utama bagi kehidupan anak. Putusnya tali ari, ketika anak dilahirkan, memang merupakan pemutusan ikatan antara ibu dengan anak secara fisik, akan tetapi hubungan antara mereka secara psikologis masih berlangsung terus, bahkan bekasnya tidak bisa terhapus sepanjang hayat. Sebab bagi anak, ibu itu merupakan lambang kasih sayang abadi dan kepadanyalah anak itu, terutama ketika masih kecil, mencari perlindungan dan mengungkapkan kasihnya. Bagi perkembangan dan pendidikan anak, kasih ibu tak bisa tergantikan.

Wanita pada dasarnya bisa mengerjakan tugas-tugasnya seperti: menggiling gandum, mengangkat air, memasak mengawetkan makanan, membetulkan dan membuat pakain, menenun, (kain, tilan, dan keranjang-keranjang), mengumpulkan makanan (kacangkacangan) buah-buahan.

\section{METODE PENELITIAN}

Penelititan ini merupakan penelitian kualitatif, penelitian kualitatif menekankan pada kejadian/ fonemena, gejala sosial yang ingin diungkap maknanya. Penelitian kualitatif dapat didesain untuk memberikan sumbangannya terhadap teori, praktisi, kebijakan, masalah sosial dan tindakan. Penelitian ini dilakukan di Daerah Lombok Timur khususnya di Desa Keruak Kecamatan Keruak Provinsi Nusa Tenggara Barat dengan menggunakan pendekatan deskriptif kualitatif. Penelitian ini mengkaji tentang problem pendidikan anak tenaga kerja wanita indonesia (TKWI) di Desa Keruak Kecamatan Keruak Kabupaten Lombok Timur

Dalam sebuah penelitian dikenal dengan jenis dan sumber data primer dan sumber sekunder. sedangkan teknik pengumpulan data yang digunakan dalam penelitian ini, antara lain Observasi, wawancara dan Dokumentasi. 
Setelah data yang diperlukan terkumpul, kemudian data tersebut dianalisis dengan cara:

a. Reduksi data (Data Reduction) melakukan analisis data dengan cara merumuskan, memilih hal-hal pokok, menfokuskan pada hal-hal penting, dan membuat katagori sehingga memberikan gambaran agar jelas serta mempermudah peneliti dalam menganalisis data.

b. Penyajian data (Display Data) mengorganisasikan data, membuat kedalam pola, membuat uraian singkat bagan, hubungan antar kategori, langkah-langkah yang dilakukan adalah; (1). data yang telah diseleksi diinternalisasikan dan direlevansikan dengan data etik, (2). informasi yang diperoleh dari wawancara diinterprestasikan untuk memberikan gambaran mendeskrifsikan fokus-fokus masalah.

c. Conclusion Drawing/Verivication. Penarikan kesimpulan setelah menyajikan data peneliti akan menarik sebuah kesimpulan untuk menjawab rumusan masalah dan memberikan saran-saran berdasarkan hasil penelitian dan kesimpulam yang diambil.

\section{HASIL PENELITIAN DAN PEMBAHASAN}

\section{Problem Pendidikan Anak Yang Di Tinggalkan Ibunya Menjadi (TKW)}

Wawancara di lakukan dengan informan pokok yaitu anak yang sudah mengenyam pendidikan di tinggalkan oleh Ibunya menjadi (TKW), keluarga terdekat anak.

Seperti yang di tuturkan ( Ida, sekolah SMP, 15 tahun, menyatakan bahwa Sebelum saya ditinggakan sama ibu, saya rajin sekali masuk sekolah mulai dari SD sampai SMP dan sering saya dapat juara sepuluh besar di sekolah, tapi sekarang setelah di tinggalka ibu di sekolah saya selalu kepikiran adik saya terus, di rumah tidak ada kesempatan untuk belajar, ibu tidak ada kabar-kabarnya sampai Satu Tahun, adik tidak ada yang gendong di rumah dan pekerjaan saya pulang sekolah saya bungkus jajan sambilan gendong adik yang masih berumur Dua Tahun karena Bapak pergi bekerja dari pagi sampai petang. Akhirnya saya mengambil keputusan untuk berhenti sekolah temanin adik di rumah, menggendongnya, memberi dia makan, minum, dan mencucikan dia pakainnya yang sudah kotor).

Berdasarkan hasil wawancara di atas Kedudukan sumi, istri dan orang tua ditentukan oleh kewajiban-kewajiban di dalam keluarga dengan pekerjaannya maupun masyarakat luas. Dengan menentukan pekerjaan-pekerjaan tertentu anak jadi terbebani dengan pekerjaannya sampai-sampai hak dalam mendapatkan pendidikan jadi gagal kerena pekerjaannya. 
Kepergian seorang ibu bisa menambah beban bagi anak-anak nya, kalau dalam kepergiannya meningalkan anak yang masih kecil. Apalagi anaknya yang masih kecil itu di bebankan pada anak-anaknya yang masih usia sekolah, di sekolah anak tidak pernah konsentrasi dalam menerima pelajaran. Selalu kepikiran rumah terus karena ada seorang adik yang membutuhkan bantuannya di rumah.

Berbeda dengan yang di tuturkan seorang anak yang benama lia, sekolah SMA, umur 17 tahun menyatakan bahwa Sebelum di tinggalkan sama orang tua merantau pergaulan dengan teman-teman di batasi, selalu di tekan untuk belajar untuk mempertahankan perestasi, tetapi setelah di tinggalkan saya bebas bergaul dengan siapa saja baik laki-laki maupun perempuan, karena orang tua laki-laki tidak pernah mempertanyakan kegiatanku seharian ketika dia pergi bekerja, dia terlalu sibuk dengan pekerjaan, apalagi menanyakan pelajaran. Tetapi masalah keuangan sekolah tetap di kasih kalau kita minta).

Berdasarkan hasil kutipan di atas, sikap orang tua sangat mempengaruhi perkembangan anak. Sikap menerima anak atau menolak, sikap kasih sayang atau acuh tak acuh, sikap melindungi atau membiarkan secara langsung memengaruhi reaksi emosional anak. Kepergian seorang ibu membuat seorang anak bebas bergaul sama teman-temannya. Keluar masuk rumah pagi malem di anggap sama karena ingin memperoleh kebahagian di luar sama teman-temanya. Di sini anak tidak bisa membedakan teman yang cocok dalam bergaul karena kontrol orang tua terhadap anaknya sangat kurang. Anak jadi begitu karena seorang anak sudah merasa tidak terurus dan tidak di pedulikan sama keluarganya.

Hal itu juga senada di ungkapkan oleh seorang anak bernama Hus, umur 13 Tahun Sejak saya berumur 10 Tahun saya sudah merasa kehilangan kedua orang tua, karena perceraian, setelah perceraian tersebut ibu saya pergi ke Malaysia, dan hak asuh aku dan adik-adikku sepenuhnya di serahkan pada nenekku, sedangkan nenekku sudah tua, setiap aku minta uang saku tidak pernah dikasih, karena untuk makan seharian saja pas-pasan, sementara ibuk ku tidak ada kabar berita sampai sekarang. Akhirnya saya memutuskan untuk berhenti sekolah dan mencari pekerjaan untuk adik-adikku pada tetangga sebagai buruh tani agar adik-adikku bisa bersekolah.

Memelihara dan membesarkan anak merupakan tanggung jawab alami yang harus di laksanakan oleh orang tua, karena si anak memerlukan makanan, minuman, dan perawatan yang cukup agar ia bisa hidup secara berkelanjutan dan juga agar bisa menikmati bangku sekolah. 
Berdasarkan hasil riset bahwa pekerjaan guru (pendidik) di sekolah akan lebih efektif apabila dia mengetahui latar belakang dan pengalaman anak didik di rumah tangganya. Anak didik yang kurang maju dalam pelajaran, berkat kerja sama orang tua anak didik dengan pendidik, banyak kekurangan anak didik yang dapat di atasi.

Kedudukan sumi istri dan orang tua ditentukan oleh kewajiban-kewajiban di dalam keluarga maupun masyarakat luas. Dengan menentukan pekerjaan-pekerjaan tertentu para lelaki di luar rumah tangga, masyarakat juga ikut menentukan pembagian kerja di dalam keluarga, sama halnya dengan apa yang dikerjakan anak-anak dan orang tua di dalam keluarga membentuk tugas-tugas apa yang akan diberikan kepada mereka di luar keluarga. Orang tua berkewajiban untuk pertama kali mensosialisir anak-anak mereka, tetapi dengan demikian pula mampertahankan kontrol sosial atas mereka jika mereka meninggalkan rumah ${ }^{9}$

\section{Kesimpulan}

Pendidikan adalah tanggung jawab bersama antara keluarga, masyarakat, dan pemerintah. Sekolah hanyalah pembantu kelanjutan dalam keluarga sebab pendidikan yang pertama dan utama di peroleh anak adalah dalam keluarga. Peralihan bentuk pendidikan jalur luar sekolah ke jalur pendidikan sekolah ( formal ) memerlukan kerja sama antara orang tua dan sekolah. Adapun masalah-masalah yang muncul pada anak TKW sebagai berikut:

Pertama Putus sekolah, Kepergian ibu anak-anak sebagai tenaga kerja wanita (TKW) membawa dampak pada pendidikan anak, karena seorang suami tidak bisa memberikan motivasi yang cukup dalam hal pendidikan ke pada anak-anaknya dan juga membawa beban bagi anak-ank yang di tinggalkan. Anak yang merasa sangat terbebani adalah anak yang paling dewasa.

Kedua Perestasi disekolah menurun, Kepergian seorang ibu seorang anak merasa kehilangan kasih sayang dari ibu dan ini bisa menambah beban bagi anak-anak nya. Apalagi anak-anak yang di tinggalin masih dalam usia bersekolah.

Ketiga Bebas dalam pergaulan, Kepergian seorang ibu membuat seorang anak merasa kehilangan sosok yang biasa mengerti dirinya, sosok yang mereka anggap malaikat baginya, disetiap saat mereka butuh sesuatu ibu selalu menjadi yang pertama meberikan kebutuhannya. Sehingga ketika mereka ditinggalkan ibunya sebagai (TKW),

\footnotetext{
${ }^{9}$ William j. Goode. Sosiologi Keluarga. (Jakarta: PT. Bumi Aksara 2004), 136.
} 
mereka mencari kesenangan lain yang mereka anggap bisa membahagiakan dirinya. Sehingga lambat laun menjadikan anak terbiasa hidup diluar rumah dengan kebiasaankebiasaan yang tidak pantas.

\section{Daftar pustaka}

Hasbullah. 2005, Dasar-dasar Ilmu Pendidikan. Jakarta: PT, Raja Grafindo Persada.

Suherman. 2003. Psikologi Keluarga. Jakarta: PT. Rineka Cipta.

Goode. J. William, 2004. Sosiologi Keluarga. Jakarta: PT. Bumi Aksara.

Bagong, Suyanto J. Dwi Narwoko. 2004. Sosiologi Teks Pengantar dan Terapan. Jakarta: Kencana Media Group

Sunarto, Kamanto. 1993. Pengantar Sosiologi. Jakarta: Lembaga Penerbit FE-UI.

Djumialdji, F.X, 1982 Perjanjian Perburuhan dan Hubungan Perburuhan Pancasila, Jakarta: Sinar Grafika

Nasihin Ulwan, Abdullah 2012. Tarbiyatu al-Aulaad Fii al-Islaam, Jakarta: Pustaka Amani, 